\title{
STRUCTURAL STUDY OF ISOFLAVONOIDS POSSESSING ANTIOXIDANT ACTIVITY ISOLATED FROM THE FERMENTATION BROTH OF STREPTOMYCES SP.
}

\author{
Shinji Funayama, Yumi Anraku, Akira Mita, Kanki Komiyama \\ and SATOSHI OMURA*
}

The Kitasato Institute, and School of Pharmaceutical Sciences, Kitasato University, 5-9-1 Shirokane, Minato-ku, Tokyo 108, Japan

(Received for publication April 17, 1989)

\begin{abstract}
Structures of three antioxidant isoflavonoids isolated from the cultured broth of Streptomyces sp. OH-1049 were shown to be $4^{\prime}, 7,8$-trihydroxyisoflavone (1), 3', $4^{\prime}, 7$-trihydroxyisoflavone (2) and 8-chloro-3',4',5,7-tetrahydroxyisoflavone (3), respectively. Among them, 3 is a novel isoflavonoid possessing a chlorine atom in the molecule.

Compound 1 was synthesized and its antitumor activities were tested against IMC carcinoma, S180, P388 leukemia and P388/ADM leukemia in vivo. As a result, 1 showed $139 \%$ increase in life span (ILS) against S180 bearing mice whereas it showed slight or no ILS against IMC carcinoma, P388 leukemia and P388/ADM leukemia bearing mice.
\end{abstract}

In the course of a screening program for novel antibiotics showing antioxidant activity, three active components were isolated from the fermentation broth of Streptomyces sp. OH-1049 and characterized as 4',7,8-trihydroxyisoflavone (1), 3',4',7-trihydroxyisoflavone (2) and 8-chloro-3',4',5,7tetrahydroxyisoffavone (3), respectively.

The taxonomy of the producing organism, fermentation, and isolation of the active components and antioxidant and anti HeLa $S_{3}$ activities of these antibiotics were reported in the preceding paper ${ }^{1}$. This paper deals with the physico-chemical properties and structure elucidation of $1 \sim 3$ and synthesis and antitumor activity tests of $\mathbf{1}$.

\section{Materials and Methods}

General Experimental Procedures

MP's were determined using a Yanagimoto MP-3 hot stage microscope and are uncorrected. UV spectra were recorded on a Shimadzu model UV-200S spectrophotometer and IR spectra on a Jasco

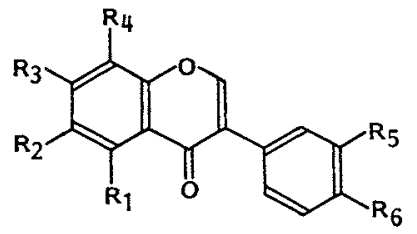

$1 \quad \mathrm{R}_{1}=\mathrm{R}_{2}=\mathrm{H} \quad \mathrm{R}_{3}=\mathrm{R}_{4}=\mathrm{OH} \quad \mathrm{R}_{5}=\mathrm{H} \quad \mathrm{R}_{6}=\mathrm{OH}$

$2 \quad \mathrm{R}_{1}=\mathrm{R}_{2}=\mathrm{H} \quad \mathrm{R}_{3}=\mathrm{OH} \quad \mathrm{R}_{4}=\mathrm{H} \quad \mathrm{R}_{5}=\mathrm{R}_{6}=\mathrm{OH}$

$3 \quad \mathrm{R}_{1}=\mathrm{OH} \quad \mathrm{R}_{2}=\mathrm{H} \quad \mathrm{R}_{3}=\mathrm{OH} \quad \mathrm{R}_{4}=\mathrm{Cl} \quad \mathrm{R}_{5}=\mathrm{R}_{6}=\mathrm{OH}$

$4 \quad \mathrm{R}_{1}=\mathrm{R}_{2}=\mathrm{H} \quad \mathrm{R}_{3}=\mathrm{OAc} \quad \mathrm{R}_{4}=\mathrm{H} \quad \mathrm{R}_{5}=\mathrm{R}_{6}=\mathrm{OAc}$

$5 \quad \mathrm{R}_{1}=\mathrm{OAc} \quad \mathrm{R}_{2}=\mathrm{H} \quad \mathbf{R}_{3}=\mathrm{OAc} \quad \mathrm{R}_{4}=\mathrm{Cl} \quad \mathrm{R}_{5}=\mathrm{R}_{6}=\mathrm{OAc}$

$6 \quad \mathrm{R}_{1}=\mathrm{OH} \quad \mathrm{R}_{2}=\mathrm{Cl} \quad \mathrm{R}_{3}=\mathrm{OH} \quad \mathbf{R}_{4}=\mathrm{R}_{5}=\mathrm{H} \quad \mathrm{R}_{8}=\mathrm{OH}$

$7 \quad \mathrm{R}_{1}=\mathrm{OH} . \quad \mathrm{R}_{2}=\mathrm{Cl} \quad \mathrm{R}_{3}=\mathrm{OH} \quad \mathrm{R}_{4}=\mathrm{Cl} \quad \mathrm{R}_{5}=\mathrm{H} \quad \mathrm{R}_{6}=\mathrm{OH}$ 
model A-102 interferometer. MS were obtained with a Jeol model DX-300 mass spectrometer. ${ }^{1} \mathrm{H}$ and ${ }^{13} \mathrm{C}$ NMR spectra were recorded on a Varian XL-400 instrument. DC-Fertigplatten Kieselgel 60 (Merck) was used for TLC analysis and for preparative TLC. TRI Rotar-V (Jasco) and Uvidec100 (Jasco) instruments were used for HPLC with a column of YMC A-303 (Yamamura Chemical Laboratory; 4.6 i.d. $\times 250 \mathrm{~mm})$ eluted with $\mathrm{MeOH}-\mathrm{H}_{2} \mathrm{O}(39: 11)$ as solvent.

Isolation of $\mathbf{1} \sim 3$

Isolation procedures of $1 \sim 3$ were described in the preceding paper ${ }^{1 /}$.

Preparation of $3^{\prime}, 4^{\prime}, 7$-Triacetoxyisoflavone (4)

Compound $2(10 \mathrm{mg})$ was acetylated using pyridine $(0.5 \mathrm{ml})$ and $\mathrm{Ac}_{2} \mathrm{O}(0.5 \mathrm{ml})$ to afford $3^{\prime}, 4^{\prime}, 7_{-}$ triacetoxyisoflavone $(4$, yield $12.0 \mathrm{mg})$.

Preparation of 8-Chloro-3',4',5,7-tetraacetoxyisoflavone (5)

Compound $3(18 \mathrm{mg})$ was acetylated using pyridine $(0.5 \mathrm{ml})$ and $\mathrm{Ac}_{2} \mathrm{O}(0.5 \mathrm{ml})$ to afford 8-chloro$3^{\prime}, 4^{\prime}, 5,7$-tetraacetoxyisofiavone $(5$, yield $9.0 \mathrm{mg})$.

Preparation of 4',7,8-Trihydroxyisoflavone (1)

4,7,8-Trihydroxyisoflavone (1) used for antitumor activity tests was prepared by applying the ethyl orthoformate method reported by KARMARKAR ${ }^{2)}$.

\section{Antitumor Activity Tests of 4',7,8-Trihydroxyisoflavone (1)}

Female $\mathrm{CDF}_{1}$ and ICR mice (6-week old) were purchased from Shizuoka Laboratory Animal Center.

Tumor cells were maintained in ascitic form by serial ip passaging in mice. Tumor cell lines and mice used in the present experiment are described in Table 2. In all tumor models, the agent was administered ip as 9 doses on days $1 \sim 9$ after tumor inoculation.

Antitumor activity of the samples on ascitic tumor was evaluated by the increase in life span (ILS): $(\mathrm{T} / \mathrm{C}-1) \times 100 \%$, where " $\mathrm{T}$ " is the mean survival days (MSD) of the treated group and "C" is the MSD of the control group.

\section{Results}

\section{Physico-chemical Properties of $1 \sim 3$}

Physico-chemical properties of $1 \sim 3$ are summarized in Table 1 and IR absorption spectrum of 3 is shown in Fig. 1. Compounds $1 \sim 3$ gave positive color reaction with iodine, $50 \%$ sulfuric acid and $\mathrm{FeCl}_{3}$ solution and was negative to ninhydrin reagent.

Table 1. Physico-chemical properties of $\mathbf{1} \sim \mathbf{3}$.

\begin{tabular}{llll}
\hline & \multicolumn{1}{c}{$\mathbf{2}$} & \multicolumn{1}{c}{$\mathbf{2}$} \\
\hline Appearance & Colorless powder & Colorless powder & \multicolumn{1}{c}{ Pale yellow powder } \\
Molecular formula & $\mathrm{C}_{15} \mathrm{H}_{10} \mathrm{O}_{5}$ & $\mathrm{C}_{15} \mathrm{H}_{10} \mathrm{O}_{5}$ & $\mathrm{C}_{15} \mathrm{H}_{9} \mathrm{O}_{0} \mathrm{Cl}$ \\
MW & 270 & 270 & 320.5 \\
Rf value & 0.23 & 0.24 & 0.36 \\
UV $\lambda_{\max }^{\mathrm{MeOH}} \mathrm{nm}$ & 260 & $248,259,292$ & $264,293(\mathrm{sh})$ \\
$\quad \lambda_{\max }^{\mathrm{MeOH}-\mathrm{NaOH} \mathrm{nm}}$ & 276 & 257,335 & $278,331(\mathrm{sh})$ \\
$\lambda_{\max }^{\mathrm{MeOH}-\mathrm{ECl}} \mathrm{nm}$ & 258 & $248,259,292$ & $264,293(\mathrm{sh})$ \\
$\mathrm{IR} \nu_{\max }^{\mathrm{KBr}} \mathrm{cm}^{-1}$ & $3460,3180,1674$, & $3440,3230,1620$, & $3340,1645,1612$, \\
& 1578,1560 & 1590 & 1259 \\
\hline
\end{tabular}

a $\mathrm{CHCl}_{3}-\mathrm{MeOH}(9: 1)$. 
Fig. 1. IR spectrum of 8-chloro-3',4',5,7-tetrahydroxyisoflavone (3) $(\mathrm{KBr})$.

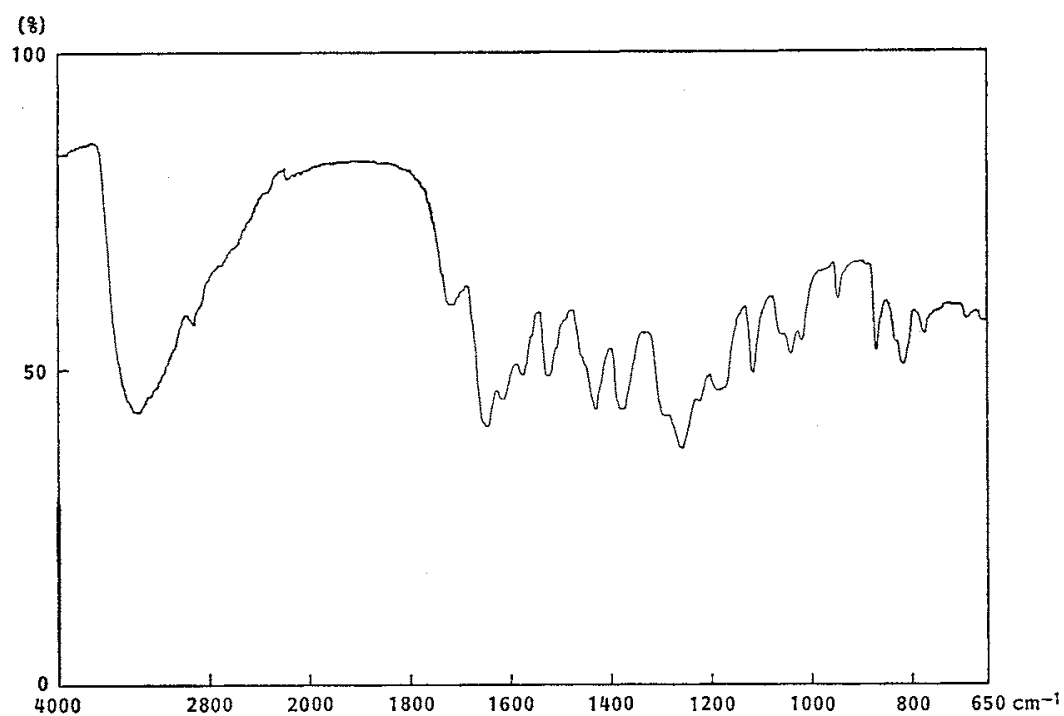

Structure Elucidation of $\mathbf{1} \sim \mathbf{3}$

Three active components $1 \sim 3$ were proved to be isoflavonoids because of their characteristic UV absorption spectra ${ }^{3)}$ and the existence of lower field singlet in their ${ }^{1} \mathrm{H}$ NMR at $\delta 8.22,8.07$, and 8.17 , respectively.

In the fast atom bombardment (FAB)-MS of $1,293\left((\mathrm{M}+\mathrm{Na})^{+}\right)$was observed and the molecular formula of this compound was estimated to be $\mathrm{C}_{15} \mathrm{H}_{10} \mathrm{O}_{5}$. On the other hand, in the ${ }^{1} \mathrm{H}$ NMR spectrum of this compound signals attributed to seven hydrogens were observed including a set of $\mathrm{A}_{2} \mathrm{~B}_{2}$ type signals attributed to B-ring of the isoflavone skeleton $(\delta 6.93(2 \mathrm{H}, \mathrm{d}, J=8 \mathrm{~Hz})$ and $7.46(2 \mathrm{H}, \mathrm{d}$, $J=8 \mathrm{~Hz}))$ and a set of doublet $(\delta 6.93(1 \mathrm{H}, \mathrm{d}, J=8 \mathrm{~Hz})$ and $7.53(1 \mathrm{H}, \mathrm{d}, J=8 \mathrm{~Hz}))$. The bathochromic shift of the UV absorption maximum (Band II) from 260 to $270 \mathrm{~nm}$ by addition of $\mathrm{NaOAc}$ indicated the presence of 7-OH moiety in the structure ${ }^{3>}$ and the set of doublet signals was assigned to 6-H and 5-H, respectively. From the accumulated data described above, structure $\mathbf{1}$ was concluded to be $4,7,8$-trihydroxyisoflavone.

The molecular formula of 2 was established to be $\mathrm{C}_{15} \mathrm{H}_{10} \mathrm{O}_{5}$ through high resolution (HR)-MS analysis $\left(\mathrm{M}^{+}\right.$obsd 270.052, calcd for $\mathrm{C}_{15} \mathrm{H}_{10} \mathrm{O}_{5}$ 270.053). In the ${ }^{1} \mathrm{H}$ NMR spectrum of 2 , three signals coupled each other at $\delta 6.81(1 \mathrm{H}, \mathrm{dd}, J=2$ and $8 \mathrm{~Hz}), 6.82(1 \mathrm{H}, \mathrm{d}, J=2 \mathrm{~Hz})$ and $8.03(1 \mathrm{H}, \mathrm{d}$, $J=8 \mathrm{~Hz}$ ) were assigned to $6-\mathrm{H}, 8-\mathrm{H}$ and $5-\mathrm{H}$, respectively and the other set of three signals $(\delta 6.84$ $(1 \mathrm{H}, \mathrm{d}, J=8 \mathrm{~Hz}), 6.92(1 \mathrm{H}, \mathrm{dd}, J=2$ and $8 \mathrm{~Hz})$ and $7.01(1 \mathrm{H}$, dd, $J=2 \mathrm{~Hz}))$ was assigned to the B-ring of the isoflavone skeleton. Finally, the structure of 2 was concluded to be $3^{\prime}, 4^{\prime}, 7$-trihydroxyisoflavone through the NMR spectroscopic studies of the triacetyl derivative of 2 (4).

It was found that compound 3 contained a chlorine atom in the molecule through MS analysis and the molecular formula of this compound was established by HR-MS to be $\mathrm{C}_{15} \mathrm{H}_{9} \mathrm{O}_{8} \mathrm{Cl}\left(\mathrm{M}^{+}\right.$obsd 320.004 and 322.002, calcd for $\mathrm{C}_{15} \mathrm{H}_{9} \mathrm{O}_{6} \mathrm{Cl} 320.008$ and 322.006). By acetylation of this compound, tetraacetate $\left(5, \mathrm{M}^{+} 488\right.$ and 490$)$ was obtained and in the ${ }^{1} \mathrm{H}$ NMR spectrum of 5 , a singlet at $\delta 6.59$ $(1 \mathrm{H}, 6-\mathrm{H}$ or $8-\mathrm{H})$, a set of three signals $\left(\delta 7.28\left(1 \mathrm{H}, \mathrm{d}, J=8 \mathrm{~Hz}, 5^{\prime}-\mathrm{H}\right), 7.41(1 \mathrm{H}, \mathrm{dd}, J=1\right.$ and $8 \mathrm{~Hz}$, $\left.6^{\prime}-\mathrm{H}\right)$ and $\left.7.42\left(1 \mathrm{H}, \mathrm{d}, J=1 \mathrm{~Hz}, 2^{\prime}-\mathrm{H}\right)\right)$ attributed to the B-ring, and a typical lower field singlet at 
Fig. 2. Fragments observed in the electron impact MS of 8-chloro-3',4',5,7-tetrahydroxyisoffavone (3).

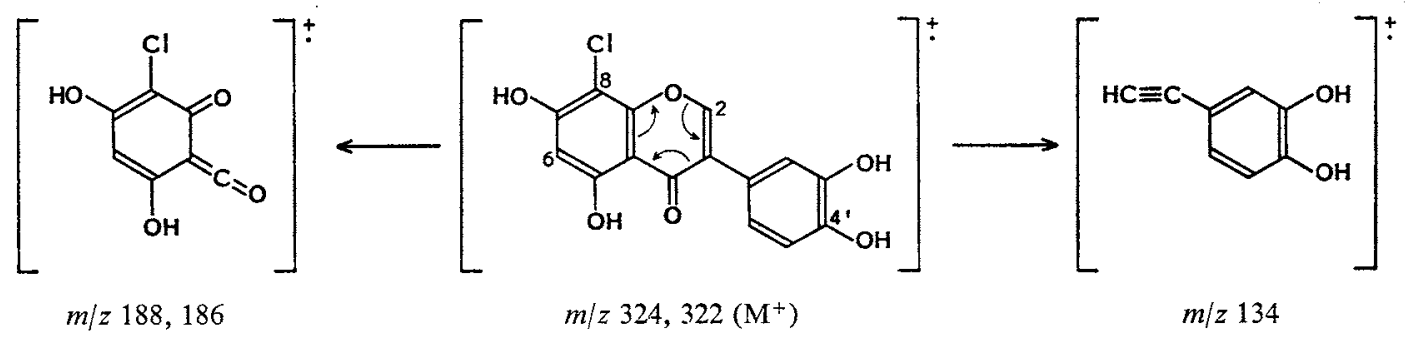

Fig. 3. LSPD experiments of 8-chloro-3',4',5,7-tetrahydroxyisoflavone (3).

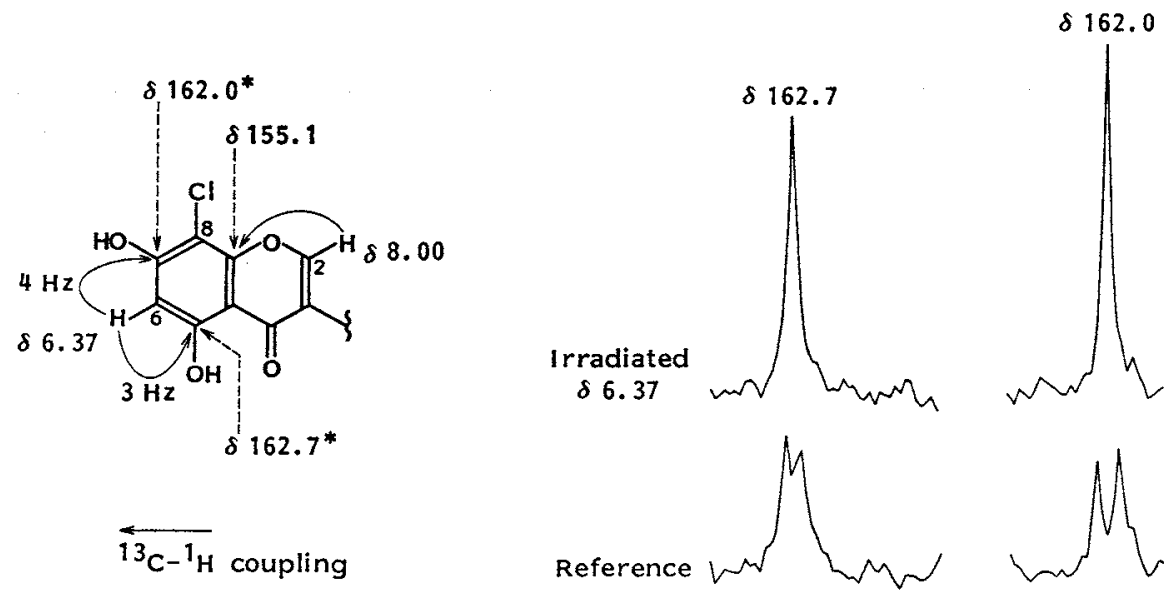

$\delta 8.00(2-H)$ were observed. These observations indicated that a chlorine atom was attached to the A-ring. The MS fragments $m / z$ 134, 186 and 188 derived from the cleavage of 3 (Fig. 2) also supported this hypothesis. In the UV absorption spectral study of $3,12 \mathrm{~nm}$ bathochromic shift was observed when the spectrum was taken in $\mathrm{MeOH}-\mathrm{NaOAc}$ and in $\mathrm{MeOH}-\mathrm{AlCl}_{3} \cdot \mathrm{HCl}$, respectively. These facts indicated that the isoflavone possessed both 7- and 5-OH. From the observations described above, structure of this compound was elucidated to be 6-chloro-3',4',5,7-tetrahydroxy-or 8-chloro$3^{\prime}, 4^{\prime}, 5,7$-tetrahydroxyisoflavone. Through the long range selective proton decoupling (LSPD) experiments of 3 , signals at $\delta 146.5$ and 147.2 were assigned to $\mathrm{C}-3^{\prime}$ and $\mathrm{C}-4^{\prime}$, respectively and $\delta 155.1$ was assigned to C-8a position because this signal was simplified by the irradiation at $\delta 8.00(2-\mathrm{H})$ and $\delta 162.0^{*}$ and $162.7^{*}$ were assigned to $\mathrm{C}-5$ and $\mathrm{C}-7$ (*exchangeable). When a singlet at $\delta 6.37(1 \mathrm{H}, \mathrm{s}$, 6-H or 8-H) was irradiated, it was observed that both of the signals at $\delta 162.0$ and $162.7(\mathrm{C}-5$ and C-7) was simplified to be singlets (Fig. 3). From these observations the singlet at $\delta 6.37$ was assigned to 6-H and the structure of this compound was concluded to be 8-chloro-3',4',5,7-tetrahydroxyisoflavone (3). ${ }^{13} \mathrm{C}$ NMR assignments of 3 are accomplished as follows: 155.0 (C-2), 125.3 (C-3), 182.3 (C-4), 106.9 (C-4a), 162.0 (C-5 or C-7), 100.8 (C-6), 162.7 (C-7 or C-5), 99.7 (C-8), 155.1 (C-8a), $123.7\left(\mathrm{C}-1^{\prime}\right)$, $117.7\left(\mathrm{C}-2^{\prime}\right), 146.5\left(\mathrm{C}-3^{\prime}\right), 147.2\left(\mathrm{C}-4^{\prime}\right), 116.6\left(\mathrm{C}-5^{\prime}\right)$ and $122.1\left(\mathrm{C}-6^{\prime}\right)$.

Antitumor Activity Tests of $4^{\prime}, 7,8$-Trihydroxyisoflavone (1)

Antitumor activities of $\mathbf{1}$ are shown in Table 2. 
Table 2. Antitumor activity of $4^{\prime}, 7,8$-trihydroxyisoflavone (1).

\begin{tabular}{|c|c|c|c|c|}
\hline Tumor & $\begin{array}{l}\text { Inoculum size } \\
\text { and mice }\end{array}$ & $\begin{array}{c}\text { Dose } \\
(\mathrm{mg} / \mathrm{kg} / \text { day })\end{array}$ & MSD & $\begin{array}{l}\text { ILS } \\
(\%)\end{array}$ \\
\hline \multirow[t]{3}{*}{ IMC carcinoma } & \multirow[t]{3}{*}{$1 \times 10^{6} \mathrm{cells} / \mathrm{CDF}_{1}$} & - & 14.7 & 0 \\
\hline & & 25 & 17.7 & 20 \\
\hline & & 100 & 20.0 & 36 \\
\hline \multirow[t]{3}{*}{ S180 } & \multirow[t]{3}{*}{$1 \times 10^{6} \mathrm{cells} / \mathrm{ICR}$} & - & 11.0 & 0 \\
\hline & & 25 & 14.7 & 33 \\
\hline & & 100 & 26.3 & 139 \\
\hline \multirow[t]{3}{*}{ P388 leukemia } & \multirow[t]{3}{*}{$1 \times 10^{5} \mathrm{cells} / \mathrm{CDF}_{1}$} & - & 9.0 & 0 \\
\hline & & 25 & 9.6 & 7 \\
\hline & & 100 & 10.0 & 11 \\
\hline \multirow[t]{3}{*}{ P388/ADM leukemia } & \multirow[t]{3}{*}{$1 \times 10^{5} \mathrm{cells} / \mathrm{CDF}_{1}$} & - & 9.5 & 0 \\
\hline & & 25 & 10.0 & 5 \\
\hline & & 100 & 10.0 & 5 \\
\hline
\end{tabular}

\section{Discussion}

A novel antibiotic, 8-chloro-3',4',5,7-tetrahydroxyisoflavone (3) was isolated from the cultured broth of Streptomyces sp. OH-1049 together with 4',7,8-trihydroxyisoflavone (1) and $3^{\prime}, 4^{\prime}, 7$-trihydroxyisoflavone (2). Compounds $1 \sim 3$ are attributed to 8-hydroxy- and 3'-hydroxydaidzein and 8-chloroorobol, respectively.

Though compound 1 was synthesized previously ${ }^{2)}$, this is the first report of its isolation from the natural source. Compound 2 was previously isolated from the heartwood of Machaerium villosum (Leguminosae) $^{4)}$, whereas this is the first report of its isolation as a fermentation product. Also, this is the first report of the antioxidant activities of compounds $\mathbf{1}$ and $\mathbf{2}$.

Compound 3 is a novel isoflavonoid containing a chlorine atom in the molecule. The only known chlorinated isoflavonoids previously isolated are 6-chlorogenistein (6) and 6,3'-dichlorogenistein (7) which are metabolites of Streptomyces griseus grown in media containing soybean mea ${ }^{5)}$.

Compound 1 was synthesized and its antitumor activity was tested. As indicated in Table 2, 1 showed remarkable ILS on S180 bearing mice and slight ILS on IMC carcinoma transplanted mice, but 1 showed no ILS on P388 or P388/ADM leukemia bearing mice.

$\alpha$-Tocopherol has been proposed for treatment of the cardiotoxicity caused by doxorubicin ${ }^{\beta}$. The mechanism of this protection is unknown, but it has been postulated that antioxidation is involved. Since compound 1 not only possesses an antioxidant activity but also possesses antitumor activity, it could play an important role in the treatment of tumors.

We are now investigating further the biological activities of these compounds and their related compounds. The results will be reported elsewhere.

\section{Acknowledgment}

This work was supported in part, by Grants-in-Aid from the Ministry of Health and Welfare, the Ministry of Education, Science and Culture, Japan, and by funds from Japan Keirin Association.

\section{References}

1) Komiyama, K.; S. Funayama, Y. Anraku, A. Mrta, Y. Taxahashi, S. Omura \& H. Shimasaki: Isolation of isoflavonoids possessing antioxidant activity from the fermentation broth of Streptomyces sp. J. Antibiotics 42: $1344 \sim 1349,1989$

2) Karmarkar, S. S.: Chromones. XXXIII. Further applications of the ethyl orthoformate method for the synthesis of isoflavones. J. Sci. Ind. Res. 20B: 334 338, 1961

3) Mabry, T. J.; K. R. Markham \& M. B. Thomas $(E d$.$) : The Systematic Identification of Flavonoids.$ Springer-Verlag, 1970 
4) DE Oliveira, A.B.; O.R. Gottlieb \& W. D. Ollis: A Química de Leguminosas Brasileiras. XVII. Constituintes do Machaerium villosum. An. Acad. brasil. Ciénc. 40:147 150, 1968

5) KöNIG, W. A.; C. KRAuSS \& H. ZÄHNER: Stoffwechselprodukte von Mikroorganismen. 6-Chlorgenistein und 6,3'-Dichlorgenistein. Helv. Chim. Acta 60:2071 2078, 1977

6) Myers, C. E.; W. MCGuire \& R. Young: Adriamycin: Amelioration of toxicity by $\alpha$-tocopherol. Cancer Treat. Rep. 60: 961 962, 1976 